\title{
Journal of

\section{Original Article}

\section{A clinical study of newly-diagnosed colorectal cancer over 2 years in a gastroenterology center in Iraq}

\author{
Abdulhadi Alrubaie (i) ${ }^{a, *}$, Nawal Alkhalidi ${ }^{b}$, Summar Abd-Alhusain ${ }^{c}$ \\ a University of Baghdad, Alkindy College of Medicine, Baghdad, Iraq \\ ${ }^{b}$ Ministry of Health, Gastroenterology Center, Baghdad, Iraq \\ c Kirkuk Medical College, Kirkuk, Iraq
}

\section{A R T I C L E I N F O}

\section{Article history:}

Received 14 April 2019

Accepted 27 May 2019

Available online 27 June 2019

\section{Keywords:}

Colorectal cancer

Colonoscopy

Rectosegmoid cancer

\begin{abstract}
A B S T R A C T
Background and study aims: Colorectal cancer (CRC) is the most common gastrointestinal cancer and the third most commonly diagnosed malignancy affecting about one million individuals each year. The etiology for most cases of CRC appears to be related to environmental factors. This study to describe the main characteristics of this malignancy regarding age, gender, and anatomical sub site distribution, as well as the main presenting symptoms in Iraqi patients.

Patients and methods: Patients with newly-diagnosed CRC by colonoscopy findings and confirmed by histopathological examination of endoscopic colonic biopsies were studied.

Results: Sixty three cases with a newly-diagnosed CRC were included in this study. There were 31 (49.2\%) males and 32 (50.8\%) females. CRC peaked in the 60-69 years old age group $(\mathrm{p}<0.05)$, more than $60 \%$ were between 40 and 69 years old. Fresh bleeding per rectum was the most common symptom occurred in $48(76.2 \%)$ patients; while the least common was weight loss (19\%). The mean duration of symptoms before referral was $7.3 \pm 12.6$ months. The tumor sites of the CRC were the rectum and sigmoid region seen in $77.8 \%(p<0.05)$, the rectum alone reported in 37 patients (58.7\%); followed by sigmoid colon in 12 (19\%) patients, cecum in $7(11.1 \%)$ patients and the ascending colon seen in $2(3.2 \%)$ patients.

Conclusions: In this study CRC occurs in relatively younger age groups in comparison to studies in the developed countries with rectal cancer predominates of all colorectal cancers.

(C) 2019 Sociedade Brasileira de Coloproctologia. Published by Elsevier Editora Ltda. This

is an open access article under the CC BY-NC-ND license (http://creativecommons.org/
\end{abstract}

licenses/by-nc-nd/4.0/).

\footnotetext{
* Corresponding author.

E-mail: hadirubaie@yahoo.com (A. Alrubaie).
}

https://doi.org/10.1016/j.jcol.2019.05.010

2237-9363/@ 2019 Sociedade Brasileira de Coloproctologia. Published by Elsevier Editora Ltda. This is an open access article under the CC BY-NC-ND license (http://creativecommons.org/licenses/by-nc-nd/4.0/). 


\title{
Estudo clínico de câncer colorretal recém-diagnosticado por 2 anos em um centro de gastroenterologia no Iraque
}

\author{
R E S U M O
}

Palauras-chave:

Câncer colorretal

Colonoscopia

Câncer retossigmoide
Contexto e objetivos do estudo: O câncer colorretal é a neoplasia gastrointestinal mais comum e o terceiro tumor maligno mais comumente diagnosticado, afetando cerca de um milhão de pessoas anualmente. A etiologia da maioria dos casos de câncer colorretal parece estar relacionada a fatores ambientais. Este estudo descreve as principais características dessa neoplasia quanto à idade, gênero e distribuição anatômica do subsite, bem como os principais sintomas observados em pacientes iraquianos.

Pacientes e métodos: O estudo avaliou pacientes com câncer colorretal recém-diagnosticado por achados de colonoscopia e confirmados por exame histopatológico de biópsias endoscópicas do cólon.

Resultados: O estudo incluiu 63 casos de pacientes com câncer colorretal recémdiagnosticado; 31 (49,2\%) homens e 32 (50,8\%) mulheres. O câncer colorretal atingiu o pico na faixa etária de 60 a 69 anos ( $\mathrm{p}<0,05)$; mais de $60 \%$ dos pacientes tinham entre 40 e 69 anos de idade. O sangramento retal fresco foi o sintoma mais comum em 48 (76,2\%) pacientes; o sintoma menos comum foi a perda de peso (19\%). A duração média dos sintomas antes do encaminhamento para especialista foi de 7,3 $\pm 12,6$ meses. Os principais sítios tumorais do câncer colorretal foram a região do reto e sigmoide em $77,8 \%$ dos pacientes $(p<0,05)$ e o reto isolado em 37 pacientes (58,7\%); seguido por cólon sigmoide em 12 pacientes (19\%), ceco em sete $(11,1 \%)$ e cólon ascendente em dois pacientes $(3,2 \%)$.

Conclusões: No presente estudo, o câncer colorretal foi observado em grupos etários relativamente mais jovens do que em estudos conduzidos em países desenvolvidos; a neoplasia retal foi o tipo de câncer colorretal mais comumente observado.

○ 2019 Sociedade Brasileira de Coloproctologia. Publicado por Elsevier Editora Ltda. Este

é um artigo Open Access sob uma licença CC BY-NC-ND (http://creativecommons.org/ licenses/by-nc-nd/4.0/).

\section{Introduction}

Colorectal cancer (CRC), the most common gastrointestinal cancer, is an important global health problem. Worldwide, CRC is the third most commonly diagnosed malignancy after lung and breast cancer. ${ }^{1}$ It affects more than one million individuals each year and causes 694,000 deaths in both sexes with almost equal gender distribution. ${ }^{2}$ Although CRC occurs mainly in Western and industrialized countries the incidence of this neoplasm has also increased in traditionally low-incidence regions since $1950 .{ }^{3}$ The incidence of CRC is influenced more heavily by age than any other demographic variable. Sporadic CRC is rarely diagnosed before the age of 40. The incidence of this malignancy increases dramatically between 45 and 50 years of age, with $90 \%$ of cases occurring after the age of 50 years; consequently, deaths from CRC begin to increase slowly in the fifth decade of life, rising steeply with advancing age. ${ }^{4,5}$

The occurrence of CRC varies greatly worldwide, with an almost 25-fold difference between specific populations in high- and low-risk regions. The highest annual incidence rates occur in Australia and New Zealand, followed by North America and Japan. Incidence tends to be lowest in middle, south central, and western Africa. ${ }^{1}$ Ethnic differences can also account for inherited predilection to CRC, African Americans suffer greater incidence and mortality due to CRC than other racial/ethnic groups in the United States and have a much lower five-year survival rate than whites. 6,7

The etiology for most cases of CRC appears to be related to environmental factors. The disease occurs more often in upper socioeconomic populations who live in urban areas. Geographic variations in incidence are unrelated to genetic differences since migrant groups tend to assume the large bowel cancer incidence rates of their adopted countries, while a high animal fat diet (western diet) is associated with a higher incidence of CRC, a low-animal fat diet (rich in fruits and vegetables) appears to be protective against the development of this malignancy. ${ }^{8-14}$

Type 2 diabetes mellitus (T2DM) has been positively associated with CRC risk in multiple observational studies; presumably because insulin and/or insulin-like growth factors have growth promoting effects in the colorectal mucosa. Patients with CRC and T2DM have a higher risk of mortality than patients with CRC who do not have T2DM. ${ }^{15}$ Excess body weight, particularly when centrally distributed (visceral adiposity) may also increase CRC risk through an insulinmediated mechanism. Of note, recent long-term follow-up data suggest that overall cancer mortality is reduced among morbidly obese patients who undergo bariatric surgery. ${ }^{16}$

Cigarette smoking has been linked to a two to threefold increase in CRC risk, most noticeably after a prolonged latency period of at least three decades. Emerging data suggest that cigarette smoking may be differentially associated with CRCs 
that exhibit microsatellite instability. ${ }^{17}$ The aim of this study is to describe the main characteristics of CRC regarding age, gender, and anatomical sub-site distribution, as well as the main presenting symptoms, in Iraqi patients.

\section{Patients and methods}

Over a two years since January 2017 we reviewed all the colonoscopy reports of patients diagnosed with CRC who had their diagnostic colonoscopy performed in the Gastroenterology and hepatic center-Baghdad. This study was approved by the ethics committee of Alkindy college of Medicine University of Baghdad. Patients were excluded if they had recurrent cancer and only patients with newly-diagnosed CRC were studied. In all patients, diagnosis was initially suspected on endoscopic findings and subsequently confirmed by the results of histopathological examination of endoscopic colonic biopsies. For all of the patients studied, the diagnosis was adenocarcinoma of varying degrees of differentiation.

Aspects included in the study were the patients' demographic and the clinical symptoms for which they have been referred for colonoscopy as well as the anatomical location of the tumor mass as described in the colonoscopy report. Five symptoms and their total duration including bleeding per rectum, diarrhea, constipation, abdominal pain, and weight loss were recorded. This descriptive statistics, correlation, and regression were used to analyze the data.

\section{Results}

Sixty three cases with a newly-diagnosed CRC and were included in this study.

Among the patients studied, there were 31 (49.2\%) males and $32(50.8 \%)$ females, with a male to female ratio of $1: 1$. The youngest patient was 27 years old while the oldest was 89 with a mean age of $55.7 \pm 15.1$ years. CRC peaked in the 60-69 years old age group $(p<0.05)$. About $16 \%$ of patients were younger than 40 years old, $22 \%$ were 70 years and older, while more than $60 \%$ were between 40 and 69 years old. Fig. 1 shows the age distribution of the patients with newly diagnosed CRC.

The most common symptom reported was fresh bleeding per rectum which occurred in 48 (76.2\%) patients; while the least common was weight loss, reported in 12 (19\%) patients. Patients' demographic and clinical characteristics are summarized in Table 1.

The shortest duration of symptoms before referral for diagnostic colonoscopy was 10 days; while the longest was 6 years. The mean duration of symptoms before referral was $7.3 \pm 12.6$ months. Twenty-five percent of patients had symptoms for one month or less, $50 \%$ for 2 months or less, $75 \%$ for 8 months or less, and $25 \%$ for more than 8 months $(p<0.05)$. Fig. 2 illustrates the relative frequencies of patients' duration of symptoms before referral for diagnostic colonoscopy.

A summary of the distribution of anatomical location of the tumors for the study patients is demonstrated in Fig. 3. By far the most common location was the rectum which was reported in 37 (58.7\%) patients; followed by the sigmoid colon, in 12 (19\%) patients; and the cecum, in 7 (11.1\%) patients,

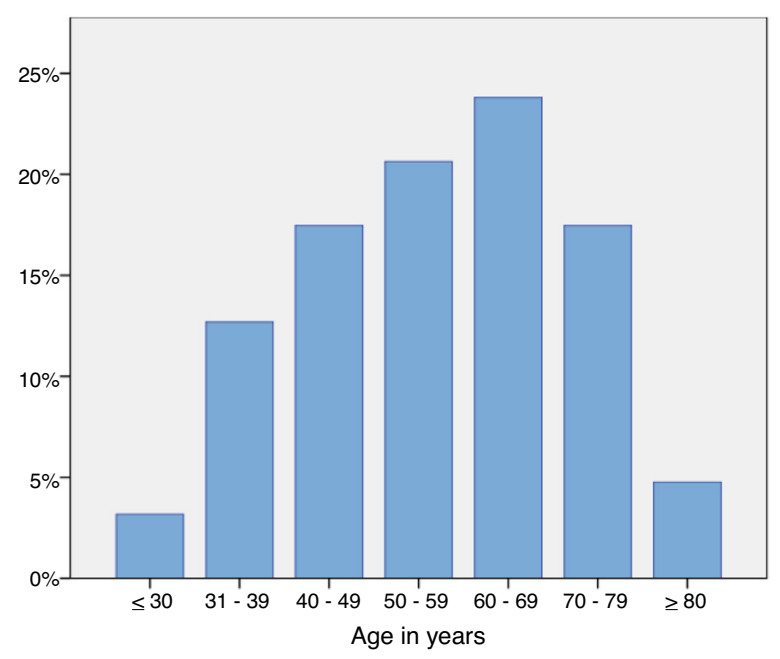

Fig. 1 - Age distribution of patients with newly diagnosed CRC.

Table 1 - Demographic and clinical characteristics of patients.

Characteristic

Values $^{a}$

Age (years)

$55.7(15.1)$

Gender

Males

$31(49.2)$

Females

$32(50.8)$

Bleeding per rectum

Constipation

$48(76.2)$

Diarrhea

$15(23.8)$

Abdominal pain $29(46.0)$

Weight loss $12(19.0)$

Duration of symptoms $^{\mathrm{b}} \quad 7.3(12.6)$

a Values are either mean (SD) or number (\%).

b Duration of symptoms measured in months.

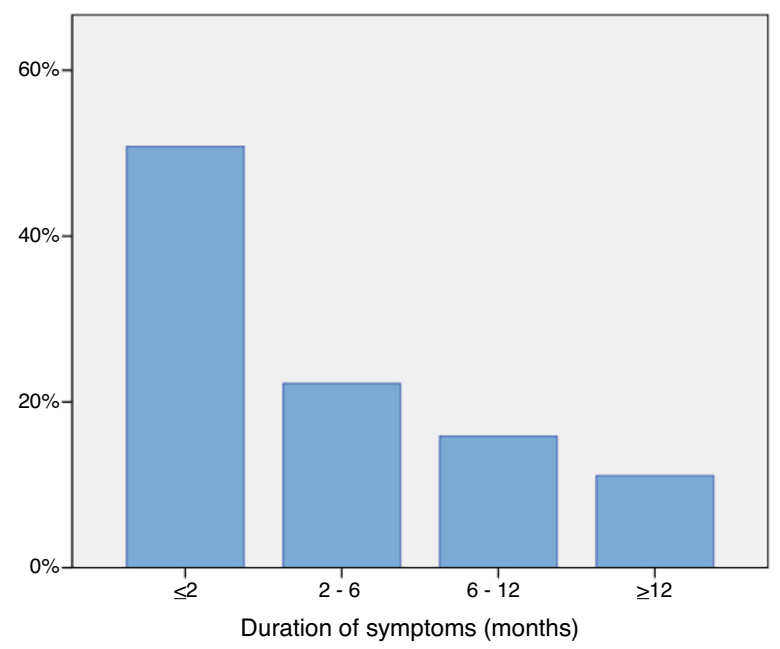

Fig. 2 - Percentage of patients by their average duration of symptoms. 


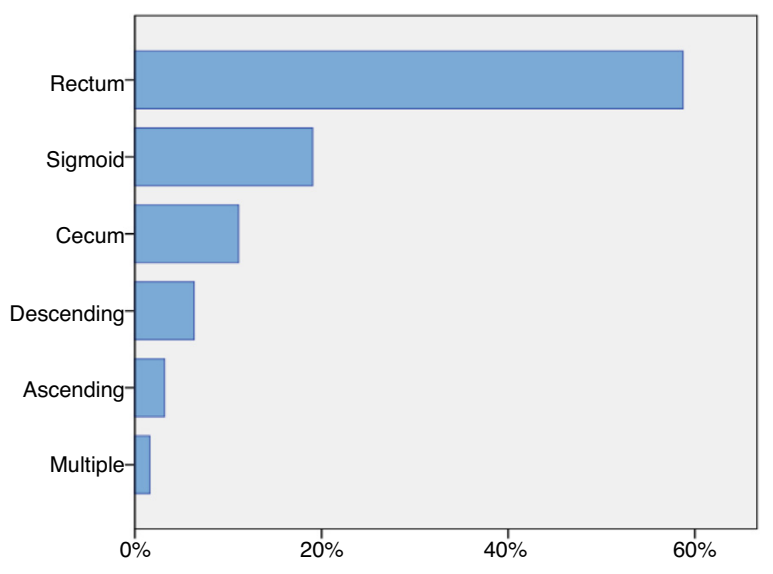

Fig. 3 - Anatomical distribution of patients' CRCs.

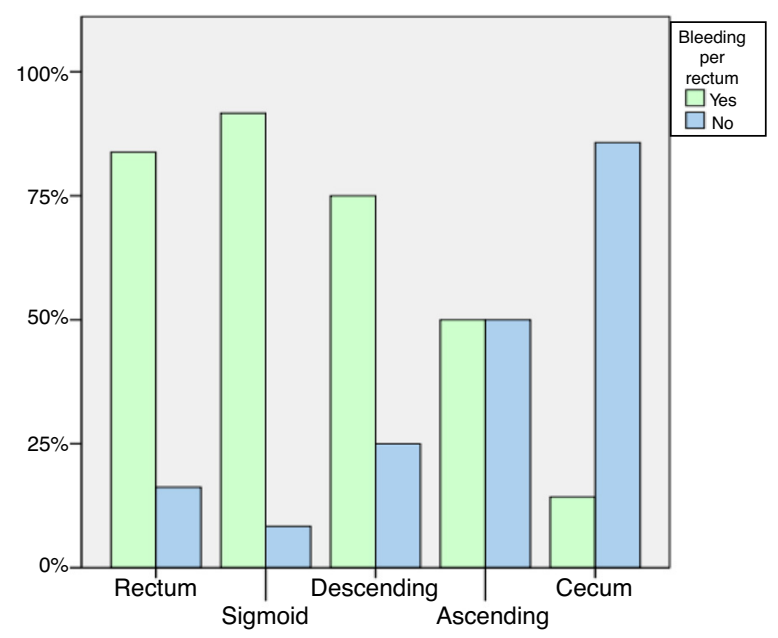

Fig. 4 - Correlation between frequency of bleeding per rectum and tumor site.

whereas the least common single site was the ascending colon, found in 2 (3.2\%) patients. Tumors of the rectum and sigmoid region were significantly more common than tumors at other sites of the colon being present in $77.8 \%$ of all CRCs diagnosed $(p<0.05)$.

Statistical analysis of presenting symptoms revealed a significant inverse relationship between the frequency of rectal bleeding and the duration of symptoms before referral for colonoscopy, so that patients with rectal bleeding tend to present earlier for colonoscopy than do patients without rectal bleeding $(p<0.01)$.

There was a significant association between tumor site and the presence of fresh rectal bleeding, so that patients with tumors in the rectosigmoid area tended to have bleeding per rectum more frequently than do patients with more proximal tumors $(p<0.01)$ this is illustrated in Fig. 4.

Patients with left-sided (distal) tumors reported abdominal pain less frequently compared to patients with right-sided (proximal) tumors $(p<0.05)$ Fig. 5. Also there was a significant correlation between the presence of weight loss and the tumor site, so that patients with distal tumors tend to report

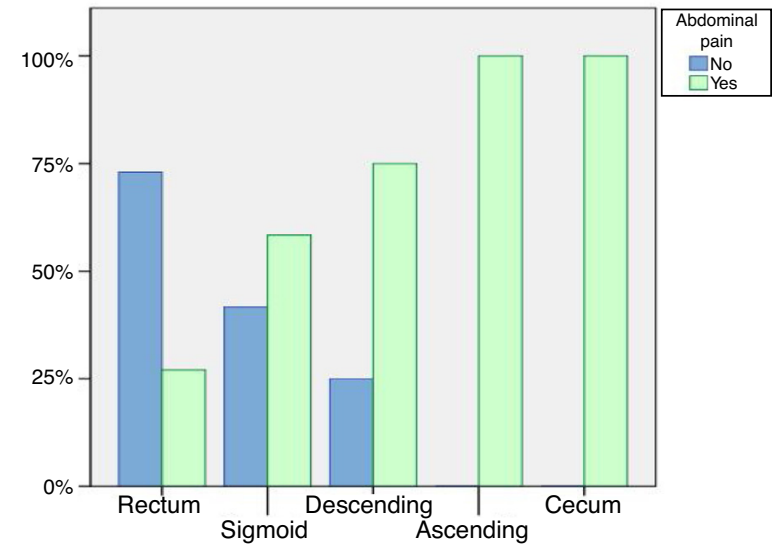

Fig. 5 - Correlation between tumor site and abdominal pain.

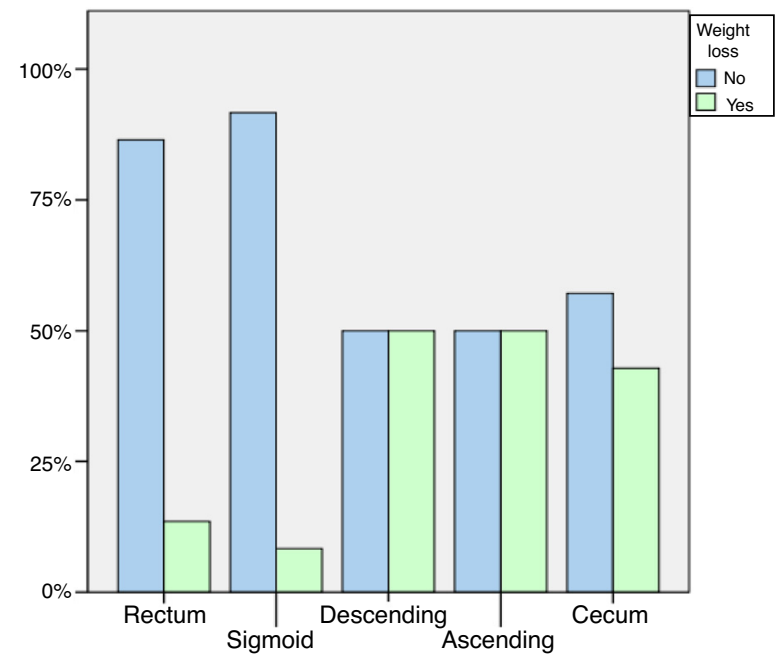

Fig. 6 - Correlation between tumor site and frequency of weight loss.

weight loss less frequently that do patients with more proximal tumors $(p<0.05)$ as shown in Fig. 6.

\section{Discussion}

The mean age of the patients with a new diagnosis of CRC in this study is 55.7 years which is not much different from 51 years and 52.3 years found in studies in Egypt and Iran, respectively. ${ }^{16,17}$ About $16 \%$ of patients in this study were younger than 40 years old and $65 \%$ were older than 50 years. This represents a trend for CRC to occur in relatively younger age groups in comparison to studies in developed countries which reports $90 \%$ of cases occurring after the age of 50 years. ${ }^{4,5}$ However, several studies in Africa reported even a higher percentage (35\%-42\%) of cases below 40 years age group. ${ }^{17,18}$ The reason for the increasing incidence in young age groups may be genetic, thus underscoring the need to study the prevalence of HNPCC associated CRC in our population however recent study in USA demonstrated an increase 
in the incidence of rectal and rectosigmoid cancer in young patients aged (<40 years). ${ }^{19}$ On the other hand, it may be related to dietary factors since young adults tend to be more likely to eat a Westernized diet. In Iraq, there has been a shift from the traditional Iraqi diet, due to upsurge in the number of fast food outlets, and it has become fashionable particularly among the youths to eat these Westernized foods which is high in animal protein and fat. ${ }^{20}$ This study showed a 1:1 male-to-female ratio in our sample of CRC cases. Most studies in other countries showed also a similar gender distribution, ${ }^{21}$ although some have shown a slight male predominance with an M:F ratio between 1.1:1 and 1.6:1, as reported in two studies in Iran and Africa, respectively. ${ }^{16,22}$ In terms of anatomical location within the large bowel, this study concurs with other studies which have indicated that the majority of CRCs are located in the distal part of the colon, ${ }^{22-27}$ however, we reported a higher figure, of $58 \%$, for rectal tumors compared to other studies and the classic literature, which report a rate of rectal cancer between $20 \%$ and $29 \%$ of all colorectal adenocarcinomas. ${ }^{28,29}$ It has been reported that the proportion of tumors beyond the reach of the sigmoidoscope increases with age and that sub site distribution also can differ according to race. ${ }^{30}$ This may partly explain the higher percentage of rectal tumors in this study where the younger-than-40 age group represented $16 \%$ of all CRC cases compared to the literature values of less than $10 \% .{ }^{30,31}$ A study in Nigeria found a similar high rate for rectosigmoid tumors compared to other subsites but they attributed their findings to the endoscopic practice in the region in which the majority of patients are offered sigmoidoscopy rather than total colonoscopy. ${ }^{28}$ This is not the case in our center where all patients have total colonoscopy unless this is technically not possible due to luminal obstruction by the tumor mass. In this study we concluded that in our country the CRC occurs in relatively younger age groups in comparison to the developed countries with rectal cancer predominates of all colorectal cancers.

\section{Conflicts of interest}

The authors declare no conflicts of interest.

\section{REFERENCES}

1. Siegel RL, Miller KD, Jemal A. Cancer statistics, 2015. CA Cancer J Clin. 2015;65:5-29.

2. Ferlay J, Soerjomataram I, Dikshit R, Eser S, Mathers C, Rebelo $\mathrm{M}$, et al. Cancer incidence and mortality worldwide: sources, methods and major patterns in GLOBOCAN 2012. Int J Cancer. 2015;136:E359-86.

3. Siegel R, DeSantis C, Jemal A. Colorectal cancer statistics, 2014. CA Cancer J Clin. 2014;64:104-17.

4. Miller AB. Trends in cancer mortality and epidemiology. Cancer. 1983;51:2413.

5. Eddy DM. Screening for colorectal cancer. Ann Intern Med. 1990;113:373.

6. Liang J, Lin C, Hu F, Wang F, Zhu L, Yao X, et al. APC polymorphisms and the risk of colorectal neoplasia: a HUGE review and meta-analysis. Am Epidemiol. 2013;177:1169-79.
7. Haenszel W, Kurihara M. Studies of Japanese immigrants. I. Mortality from cancer and other diseases among Japanese in the United States. J Natl Cancer I. 1968;40:43.

8. Whittemore AS, Wu-Williams AH, Lee M, Zheng S, Gallagher RP, Jiao DA, et al. Diet, physical activity and colorectal cancer among Chinese in North America and China. J Natl Cancer I. 1990;82:915.

9. O'Keefe SJ, Kidd M, Espitalier-Noel G, Owira P. Rarity of colon cancer in Africans is associated with low animal product consumption, not fiber. Am J Gastroenterol. 1999;94: 1373-80.

10. López PJ, Albero JS, Rodríguez-Montes JA. Primary and secondary prevention of colorectal cancer. Clinical medicine insights. Gastroenterology. 2014;7:33.

11. Magalhaes B, Peleteiro B, Lunet N. Dietary patterns and colorectal cancer: systematic review and meta-analysis. Eur J Cancer Prev. 2012;21:15-23.

12. Howe GR, Benito E, Castelleto R, Cornée J, Estève J, Gallagher $\mathrm{RP}$, et al. Dietary intake of fiber and decreased risk of cancers of the colon and rectum: evidence from the combined analysis of 13 case-control studies. J Natl Cancer Inst. 1992;84:1887.

13. Bingham S, Day NE, Luben R, Ferrari P, Slimani N, Norat T, et al. Dietary fibre in food and protection against colorectal cancer in the European Prospective Investigation into Cancer and Nutrition (EPIC): an observational study. Lancet. 2003;361:1496.

14. Giovannucci E. Modifiable risk factors for colon cancer. Gastroenterol Clin North Am. 2002;31:925-43.

15. Dehal AN, Newton CC, Jacobs EJ, Patel AV, Gapstur SM, Campbell PT. Impact of diabetes mellitus and insulin use on survival after colorectal cancer diagnosis: the Cancer Prevention Study-II Nutrition Cohort. J Clin Oncol. 2012;30:53-9.

16. Chen K, Xia G, Zhang C, Sun Y. Correlation between smoking history and molecular pathways in sporadic colorectal cancer: a meta-analysis. Int. J Clin Exp Med. 2015;8:3241.

17. El-Bolkainy TN, Sakr MA, Nouh AA, El-Din NH. A comparative study of rectal and colonic carcinoma: demographic, pathologic and TNM staging analysis. J Egypt Natl Cancer Inst. 2006;18:258-63.

18. Fazeli MS, Adel MG, Lebaschi AH. Colorectal carcinoma: a retrospective, descriptive study of age, gender, subsite, stage, and differentiation in Iran from 1995 to 2001 as observed in Tehran University. Dis Colon Rectum. 2007;50:990-5.

19. Meyer JE, Narang T, Schnoll-Sussman FH, Pochapin MB, Christos PJ, Sherr DL. Increasing incidence of rectal cancer in patients aged younger than 40 years: an analysis of the surveillance, epidemiology, and end results database. Cancer. 2010;116:4354-9.

20. Yang M, Hu FB, Giovannucci EL, Stampfer MJ, Willett WC, Fuchs CS, et al. Nut consumption and risk of colorectal cancer in women. Eur J Clin Nutr. 2015.

21. Edwards BK, Howe HL, Ries LAG, Thun MJ, Rosenberg HM, Yancik R, et al. The annual report to the nation on the status of cancer, 1973-1999, featuring implications of age and aging on US cancer burden. Cancer. 2002;94:2766-92.

22. Adekunle OO, Abioye AA. Adenocarcinoma of the large bowel in Nigerians: a clinicopathologic study. Dis Colon Rectum. 1980;23:559-63.

23. Siegel R, Naishadham D, Jemal A. Cancer statistics, 2013. CA Cancer J Clin. 2013;63:11-30.

24. Caldarella A, Crocetti E, Messerini L, Paci E. Trends in colorectal incidence by anatomic subsite from 1985 to 2005: a population-based study. Int J Colorectal Dis. 2013;28:637-41.

25. Irabor DO. Diet, environmental factors and increasing incidence of colorectal cancer in Nigeria. Ann Niger Med. 2014;8:58. 
26. Adesanya AA, da Rocha-Afodu JT. Colorectal cancer in Lagos: a critical review of 100 cases. Niger Postgrad Med J. 2000;7:129-36.

27. Sleisenger MH, Feldman M, Friedman LS, Brandt LJ. Sleisenger and Fordtran's gastrointestinal and liver disease.

Saunders/Elsevier; 2010

28. Akinola DO, Arigbabu AO. Pattern and presentation of large bowel neoplasms in Nigerians. Cent Afr J Med. 1994;40:98-102.

29. Iliyasu Y, Ladipo JK, Akang EE, Adebamowo CA, Ajao OG, Aghadiuno PU. A twenty-year review of malignant colorectal neoplasms at University College Hospital, Ibadan, Nigeria. Dis Colon Rectum. 1996;39:536-40.

30. Yamada Tadataka, Alpers David H, Owyang Chung, editors. Textbook of gastroenterology, vol. 5. Wiley-Blackwell; 2009.

31. Fatimah BA, Abudu EK, Awolola NA, Elesha SO, Rotimi O, Akinde OR, et al. Colorectal carcinoma in Lagos and Sagamu, Southwest Nigeria: a histopathological review. World J Gastroenterol. 2008;14:1007-9327. 